\title{
Substantiation of the methodology for modeling and calculating the optimal operating modes of a tandem pumping installation when mining uranium
}

\author{
Beibit Myrzakhmetov $^{1 \otimes(0)}$, Arkhat Sultabayev ${ }^{1 \otimes}$, Saltanat Toktamissova ${ }^{1 * \square(1)}$ \\ ${ }^{1}$ Satbayev University, Almaty, 50013, Kazakhstan \\ *Corresponding author: e-mail salta.mahmood@gmail.com, tel. +77477227275
}

\begin{abstract}
Purpose. The purpose of the research is to develop a mathematical model of the jet pump (JP) working process and a calculation methodology for modeling, as well as to determine the optimal operating modes of a combined pumping installation in downhole conditions.

Methods. When conducting research, the coordinated operation of an electric-centrifugal pump (ECP), a jet pump and a reservoir is determined as the initial compulsory condition for the effective exploitation of extraction wells using a tandem pumping installation (TPI). Theoretical studies describing the joint operation of a jet pump and an electric-centrifugal pump were conducted, in the course of which mathematical modeling of the "productive reservoir - electric-centrifugal pump - jet pump" system operation in a coordinated mode was used. Specific data from the Khorasan-2 deposit (Republic of Kazakhstan) mines are accepted as the initial data during the modelling. When modelling the jet pump operating modes, special attention is paid to determining the boundary parameters of the pumped-out productive solution, at which cavitation can occur. The modelling is performed using the Maple software package from Waterloo Maple Inc.

Findings. To assess the efficiency of pumping-out the productive uranium solutions from wells using tandem pumping installations, a mathematical model of the jet pump working process has been developed. On its basis, a calculation methodology for modeling the operating modes of a combined pumping installation with imitation of actual downhole conditions has been compiled.

Originality. As a result of computational modeling, the high sensitivity of the cavitation modes of the jet pump operation to the design parameters of the jet pump main elements has been revealed, while the tandem installation itself as a whole has a lower sensitivity to changes in dynamic conditions. It has been substantiated that the use of a tandem pumping scheme for pumping-out a productive uranium solution can increase the productivity and energy efficiency of the process.

Practical implications. The calculation methodology and algorithm make possible, with sufficient accuracy for practical use, to quickly calculate the required geometric parameters of the jet pump to ensure rational and cavitation-free modes of the tandem pumping installation depending on the specific downhole conditions in the "reservoir - electrical centrifugal pump - jet pump" system. In addition, it is possible to develop some practical recommendations for the design of jet pumps, working in tandem with submersible electric-centrifugal pumps.
\end{abstract}

Keywords: modelling, virtual model, pump, well, nozzle, diffuser, uranium mining, cavitation

\section{Introduction}

Submersible electric-centrifugal pumps (ECP) are widely used in the technology of uranium mining by the method of bore-hole in-situ leaching (ISL). This is conditioned by a number of their advantages such as high efficiency and head, as well as ease of automation, control, compactness and so on.

However, the wells exploitation using highly-efficient electric-centrifugal pumps is also associated with increased energy consumption, which has a significant impact on the mined products cost. The situation is worsened by high pumped-out fluid aggressiveness and a significant content of mechanical impurities in it, which is the reason for frequent failures of downhole pumping equipment and an increase in mining costs. Insufficient operational lifetime of the pumps leads to the need of reducing the permissible loads and their operation at off-design modes, hence to frequent repairs. All this leads to an increase in overhead expenses for their maintenance and repair, as well as an increase in the idle time of wells during underground repairs with pump replacement [1]-[3].

It should also be admitted that in modern designs of electric-centrifugal pumps, the maximum possible indicators have been practically achieved and a further sharp increase in their efficiency is not expected in the near future. 
Since the bulk of the production cost consists of the expenditures for electricity and underground repairs of wells to replace the pump, it is very important to select the optimal pump and the technological mode of the wells operation in general.

In this regard, a significant part of recent research is aimed at optimizing the operating modes of the existing pumping stock [1], [2], [4], [5], including through the use of combined pumping installations, which is also an essential reserve for improving the technical and economic indicators of wells exploitation. The latter means a coordinated combination of elements in the "productive reservoir - well pumping installation" system.

In the oil producing industry, intensive theoretical and practical studies are being conducted of the joint operating modes of submersible electric-centrifugal and jet pumps, the results of which confirm the prospects of using this technology in the uranium industry [6]-[8].

One of the important issues for the recommendations development in the design and practical application of tandem pumping installations in the technology of uranium mining by the method of bore-hole in-situ leaching (ISL) is the availability of calculation methodologies for modeling the operating modes of jet pumps in downhole conditions under changing dynamic conditions. While most of the existing computational modeling methods contain general recommendations or consider particular cases of their application without taking into account downhole conditions [9]-[11].

The wells exploitation with the use of highly-efficient electric-centrifugal pumps at off-design modes is associated with increased energy consumption, which has a significant impact on the mined products cost. One of the ways to increase the efficiency of submersible electric-centrifugal pumps, tested in the practice of oil production, is their sequential combination with jet pumps, called combined or tandem.

Therefore, the main purpose of this modeling method development is the calculation determination of rational design parameters of the jet pump to optimize its operating modes as part of a combined pumping installation in the "reservoir - electric-centrifugal pump - jet pump" system.

\subsection{State-of-the-art analysis in the field of tandem pumping installations application and methods for calculating their operation}

A large number of works are devoted to the choice of electric-centrifugal pumps operating mode and the assessment of their efficiency. Their analysis leads to the conclusion that the choice of the optimal mode of the well exploitation is a task with many criteria and the need to take into account a large number of factors [4], [5]. Therefore, no single method exists today.

Recent studies have shown that one of the promising ways to expand the functionality of downhole electriccentrifugal pumps can be their combination with jet pumps, namely, the use of so-called combined or tandem pumping installations [12].

In this regard, in recent years, an interest has increased in the development of new layouts and designs of tandem pumping installations consisting of electric-centrifugal pump and jet pump, as well as their use in technological processes and practice of pumping-out productive uranium solutions from wells by bore-hole in-situ leaching technology and downhole fluid production. This advantage of jet pumps is especially evident in difficult operating conditions, for example, when pumping-out solutions with a high content of mechanical impurities, aggressive corrosive substances and from directional wells. Their advantages also include simplicity of design, absence of moving parts, high reliability, small dimensions and high productivity.

Another important advantage is the automatic adjustment of tandem pumping installations when the operating conditions of wells change (changes in reservoir pressure, product properties, wells output, etc.). Since the electric-centrifugal pump and the jet pump have a direct "head - delivery" dependence. The use of a tandem installation allows to increase the total delivery of the productive solution, which makes it possible to significantly expand the control range of the electric-centrifugal pump operating mode or to use a pump with a lower delivery.

For example, the oil industry already has a number of successful and tested in practice tandem pumping installations of the Russian National University of Oil and Gas "Gubkin University" for various operating conditions [6]. Leading companies in the field such as KOBE, National OilWell, Guiberson, Wetherford, Trico Industries, Dresser Industries and others also have extensive experience in the design of efficient structures and the practice of using jet pumping installations.

Despite this, the use of tandem pumping installations when mining minerals by the method of bore-hole in-situ leaching in domestic practice is not widespread. This is caused by the difficulties in selecting the joint optimal parameters of the electric-centrifugal pump and the jet pump, insufficient reliability of calculation methodologies for determining the design parameters of the jet pump when working with multiphase fluids, determining the location of its setting in the well at various viscosities and densities of fluids, unstable flow rates and dynamic levels in it, etc. Most of the methods consider particular cases of their application and contain a large number of empirical coefficients, limiting their application [9], [13], [14].

In the jet apparatus (Fig. 1), the potential energy of the working flow, which is created by the electric-centrifugal pump 1 , is converted into kinetic energy in the high-pressure nozzle 2 . The kinetic energy of the working flow is partially transferred to the injected flow, coming from the annular space. When moving through the flow path of the jet apparatus (mixing chamber 3 ), the velocities of the mixed flows are equalized, and then the reverse transformation of the mixed flow kinetic energy into potential energy in the diffuser 4 occurs [15].

The diffuser diameter is several times (4-6) larger than the nozzle diameter, and therefore the fluid velocity decreases rapidly. The reverse process occurs of the kinetic energy transition of the working fluid into the potential energy of the injected fluid. The computational scheme of the jet pump and the nature of the fluid pressure changing as the fluid moves along its structural elements are shown in Figure 1.

The jet pump characteristics are similar to those of an submersible electric-centrifugal pump, but they are rather flat. They essentially depend on the design parameters of the jet pump elements; the ratio of the nozzle area to the mixing chamber area; nozzle diameter; the mixing chamber diameter and the distance between the nozzle and the mixing chamber; the mixing chamber length and the pressure drops of the working and injected fluids. 


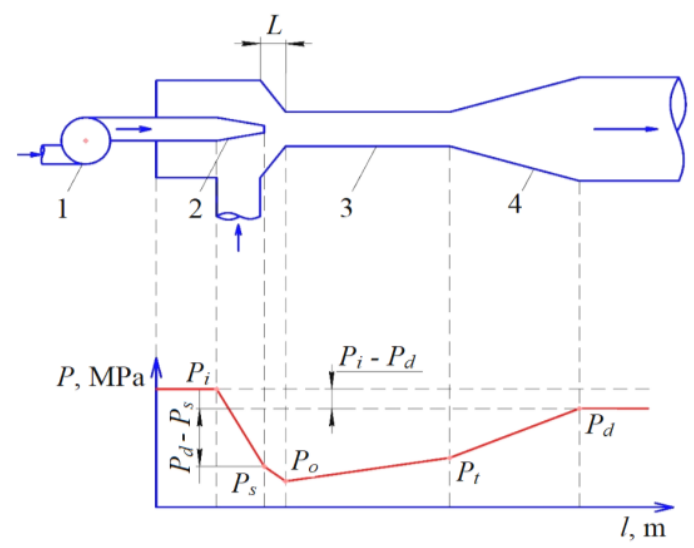

Figure 1. Pattern of change in the working fluid pressure in the jet pump: 1 -electric-centrifugal pump; 2 - high-pressure nozzle; 3-mixing chamber; 4-diffuser; $P_{i}$-working fluid pressure; $P_{s}$-pumped-out fluid pressure; $P_{t}$-pressure at the mixing chamber outlet; $P_{d}$-fluid pressure at the jet pump outlet; $L$-distance from the nozzle to mixing chamber inlet; $P_{o}$-pressure at the mixing chamber inlet; $\left(P_{d}-P_{s}\right)$-pressure rise of the pumped-out fluid in the jet pump; $\left(P_{i}-P_{d}\right)$ - pressure fall of the working fluid caused by its kinetic energy dissipation

One of the unfavourable factors, influencing significantly on the reliability of elements and the operational lifetime of pumps, is cavitation [10].

\subsection{Research purpose and objectives}

The purpose of the research is to develop a method for calculating the rational operating modes of the tandem pumping installation and the jet pump design parameters, corresponding to them, when pumping-out a productive uranium solution from the wells.

To achieve this purpose, the following objectives are set:

- substantiate the mathematical model of a hydraulic jet pump for working in tandem with an electric-centrifugal pump;

- to describe mathematically the joint operation of a downhole submersible electric-centrifugal pump and a hydraulic jet pump, which will allow to determine rational design parameters of the jet pump to ensure the optimal value of the ejection coefficient at the maximum possible efficiency, excluding the cavitation phenomenon in the jet pump elements;

- to develop practical recommendations for determining the rational design parameters of the jet pump under specified operating conditions.

\section{Method and algorithm for calculating the optimal operating modes of the combined pumping installation}

A compulsory condition for the effective extraction wells exploitation using tandem pumping installation is the coordinated operation of an electric-centrifugal pump, a jet pump and a reservoir.

The jet pump efficiency is based on a function of the following main characteristics:

- geometric parameters;

- pressure and supply of the working fluid coming from the ascending pipe of the electric-centrifugal pump;

- pressure of the injected fluid in the annular space at a depth of the jet pump setting (that is, from the dynamic level);

- jet pump discharge pressure.
The main purpose of calculating the combined pumping installation is to determine the optimal pump geometry, which will ensure the operation of the "reservoir - electriccentrifugal pump - jet pump" system in a coordinated mode.

The combined installation delivery is calculated as the sum of the electric-centrifugal pump and the jet pump deliveries, equal to the design flow rate of the extraction well. The calculation is made for the selected standard size of electric-centrifugal pump with a known characteristic.

Computational modelling is performed according to the following method.

1. Determining the productivity and pressure of the productive solution at the electric-centrifugal pump outlet at a given frequency:

$q_{1}=q_{n}\left(\frac{H z}{50}\right)$

$P_{i}=\rho \cdot g \cdot h_{n}\left(\frac{H z}{50}\right)^{2}$,

where:

$q_{1}$ - delivery of the electric-centrifugal pump at current (set) adjustment frequency, $\mathrm{m} 3 / \mathrm{h}$;

$q_{n}$ and $h_{n}$-nominal delivery and head of the electriccentrifugal pump at standard supply voltage frequency $(50 \mathrm{~Hz})$;

$\mathrm{Hz}$ - set adjustment frequency of the electric-centrifugal pump, $\mathrm{Hz}$;

$P_{i}$-solution pressure at the electric-centrifugal pump discharge at the current set frequency, $\mathrm{MPa}$;

$\rho$ - pumped-out fluid density, $\mathrm{kg} / \mathrm{m}^{3}$;

$g-$ free fall acceleration $\left(9.81 \mathrm{~m} / \mathrm{s}^{2}\right)$.

Based on Equations (1)-(2), the head-capacity characteristic of the electric-centrifugal pump for a given frequency is constructed, as well as the pressure and head of the installation at the operating point with various frequencies are also calculated.

2. Determining the pressure at the jet pump suction at the time of starting the electric-centrifugal pump:

$$
P_{s}=\left(H_{\text {pump }}-H_{d y n}\right) \cdot \rho \cdot g,
$$

where:

$P_{s}-$ pressure at the jet pump suction, $\mathrm{MPa}$;

$H_{\text {pump }}$ - depth (vertical) of the electric-centrifugal pump descent, m;

$H_{d y n}-$ dynamic fluid level from the wellhead, m.

3. Determining the pressure at the jet pump discharge:

$P_{d}=P_{D H}+H_{\text {pump }} \cdot \rho \cdot g$,

where:

$P_{d}$ - pressure at the jet pump discharge, $\mathrm{MPa}$;

$P_{D H}$ - wellhead pressure, MPa.

4. Determining the main theoretical parameter characterizing the jet pump - the ejection coefficient $N$ :

$N=\frac{\left(P_{d}-P_{s}\right)}{\left(P_{i}-P_{d}\right)}$,

where:

$P_{d}-$ pressure at the jet pump outlet, $\mathrm{MPa}$;

$P_{i}$ - pressure at the outlet from the high-pressure nozzle of the jet pump, MPa. 
5. Determining the optimal ejection coefficient for the range of the parameter $(b)$ values by differentiating and setting equal to zero of the equation (5) in the form:

$N=\frac{n_{1}}{n_{2}}$

where:

by means of $n_{1}=P_{d}-P_{s}$ and $n_{2}=P_{i}-P_{d}$ - pressure drops in Formula (5) are designated, as dimensionless coefficients, respectively.

The difference of these pressures can be expressed through the Bernoulli equation as:

$$
\begin{aligned}
& n_{1}=2 \cdot b+\frac{2 \cdot S \cdot N \cdot c^{2} \cdot b^{2}}{1-b}-b^{2} \cdot\left(1+K_{t h}+K_{d i}+a^{2}\right) \\
& (1+m) \cdot(1+S \cdot M)-\frac{S \cdot M^{2}}{c^{2}}\left(1+K_{e n}\right) \\
& n_{2}=1+K_{n}-n_{1}
\end{aligned}
$$

where:

$K_{t h}$ - pressure loss factor due to friction in the mixing chamber;

$K_{d i}$ - pressure loss factor due to friction in the diffuser;

$K_{n}$ - pressure loss factor due to friction in the nozzle;

$K_{e n}$ - pressure loss factor due to friction at the mixing chamber inlet (suction chamber);

$a$ - ratio of the nozzle area to the diffuser area;

$M$ - jet pump ejection coefficient;

$b$ - ratio of the nozzle area to the mixing chamber area;

$c$-dimensionless group, $c=\frac{1-b}{b}$;

$S$-ratio of the working and pumped-out flow density, $S=\frac{\rho_{1}}{\rho_{2}}=1$.

The optimal ejection coefficient is determined in the range of values $b=0.1 \ldots 0.9$ with setting the efficiency corresponding to a given point.

6. Determining the cavitation for various ratios of the nozzle and the mixing chamber areas according to the equation:

$M_{c}=c \cdot\left(\frac{P_{s}-P_{v}}{\sigma \cdot Z}\right)^{0.5}$,

where:

$M_{c}$ - cavitation-limited ejection coefficient;

$\sigma=1.35$ - cavitation factor;

$Z$-dynamic head, MPa;

$P_{v}$ - saturated vapour pressure, MPa.

7. Calculating the cavitation stability of the CR jet pump for each option of $(b)$ parameter:

$$
C R=\frac{M_{L}-M_{o p}}{M_{o p}} \cdot 100 \%,
$$

where:

$M_{L}$ - ejection coefficient at a given flow rate;

$M_{o p}$ - ejection coefficient at maximum efficiency.

8. Based on the calculations performed at stages 5-7, the optimal value of $(b)$ parameter is selected, the efficiency value and the optimal ejection coefficient are found.
9. Determining the nozzle diameter:

$$
\begin{aligned}
& A_{n}=\frac{q_{1}}{v_{n}}=q_{1} \frac{1}{\frac{2 \cdot\left(P_{i}-P_{s}\right)}{\rho \cdot\left(1+K_{n z}\right)}} \\
& D_{n}=\left(A_{n} \cdot \frac{4}{\pi}\right)^{2}
\end{aligned}
$$

where:

$q_{1}$ - volumetric flow rate of working fluid;

$v_{n}$ - working flow velocity in the nozzle;

$K_{n z}$ - pressure loss factor due to friction in the nozzle.

10. Determining the mixing chamber diameter based on the calculation results at stages 8-9.

11. The distance between the nozzle and the mixing chamber is taken equal to $D_{t h}$.

12. Mixing chamber length according to recommendations [11] and design experience is taken equal to:

$$
L=8 \cdot D_{t h} \text {. }
$$

13. Testing downhole conditions (well potential) for the operation of the combined installation.

To calculate a well potential, at least one measured value of the well flow rate is required, as well as the corresponding static and dynamic levels. Based on the measurement, the well output index is found $\left(\mathrm{m}^{3} /\right.$ day/MPa):

$$
K_{\text {output }}=\frac{Q_{\text {test }}}{9.81 \cdot\left(D L_{\text {test }}-D L_{\text {static }}\right) \cdot \rho \cdot 10^{-6}},
$$

where:

$Q_{\text {test }}$ - measured flow rate of the well, $\mathrm{m}^{3} / \mathrm{h}$;

$D L_{\text {test }}$ - measured dynamic level from the wellhead at a given flow rate of the well, $\mathrm{m}$;

$D L_{\text {static }}$ - measured static level from the wellhead, $\mathrm{m}$.

Then, the expected dynamic level is calculated when the combined pumping installation is operating:

$$
D L_{\text {op }}=\frac{q_{1}+q_{2}}{K_{\text {output }} \cdot 9.81 \cdot \rho}+D L_{\text {static }},
$$

where:

$q_{2}-$ jet pump delivery, $\mathrm{m}^{3} / \mathrm{h}$.

14. Stages 2-12 are repeated until the pump immersion below the dynamic level achieves the acceptable values ensuring its efficient operation.

\section{Results}

The initial data for modelling. The averaged data on the Khorasan-2 deposit uranium mines are taken as the initial data during the modelling. They include the well structure and its depth; nominal head, electric-centrifugal pump deli-very and descent; physical and chemical properties of the pumped-out fluid (density, viscosity); the well potential (measured values of the well flow rate and the corresponding static and dynamic levels, and so on.) Extraction well parameters and electriccentrifugal pump parameters are presented in Tables 1 and 2 .

When modelling the jet pump operating modes, special attention is paid to determining the boundary parameters of the fluid, at which cavitation can occur. 


\section{Table 1. Extraction well parameters}

\begin{tabular}{lc}
\hline \multicolumn{1}{c}{ Parameter } & Value \\
\hline Average well depth, $\mathrm{m}$ & 670 \\
Diameter of the gathering line pipe & 350,450 \\
from the well to the collecting tank, $\mathrm{mm}$ & $8-12$ \\
Well flow rate, $\mathrm{m}^{3} / \mathrm{h}$ & $10-15$ \\
Dynamic level fluctuation, $\pm \mathrm{m}$ & Vary in range \\
Static fluid level, $\mathrm{m}$ & from -50 to $0 \mathrm{~m}$ \\
& Vary in range \\
Dynamic fluid level, $\mathrm{m}$ & from -50 to $0 \mathrm{~m}$ \\
Extraction well flow rate, $\mathrm{m}^{3} / \mathrm{h}$ & $8-10$ \\
\hline
\end{tabular}

Table 2. Downhole pump parameters and extraction well operating mode

\begin{tabular}{|c|c|}
\hline Parameter & Value \\
\hline Well diameter, $\mathrm{mm}$ & 90 \\
\hline $\begin{array}{l}\text { Passport capacity of a multistage downhole } \\
\text { electric-centrifugal pump "Grundfos", } \mathrm{m}^{3} / \mathrm{h}\end{array}$ & 17 \\
\hline Nominal head, m, water column & 129 \\
\hline $\begin{array}{l}\text { Depth of the pump immersion } \\
\text { under the fluid level, } m\end{array}$ & to 50 \\
\hline Solution density, $\mathrm{kg} / \mathrm{dm}^{3}$ & $1.03-1.05$ \\
\hline $\begin{array}{l}\text { Lowering the static level } \\
\text { during pumping-out, } \mathrm{m}\end{array}$ & $\begin{array}{l}\text { from } 10 \mathrm{~m} \\
\text { to } 15 \mathrm{~m}\end{array}$ \\
\hline
\end{tabular}

The modelling is performed using the Maple software package from Waterloo Maple Inc., focused on complex mathematical calculations, process modelling and visualization of results.

To calculate the electric-centrifugal pump parameters, the operating characteristic of the Grunfoss SP-17-8NE pumps applied in the field is used (the characteristic is shown in Figure 2).

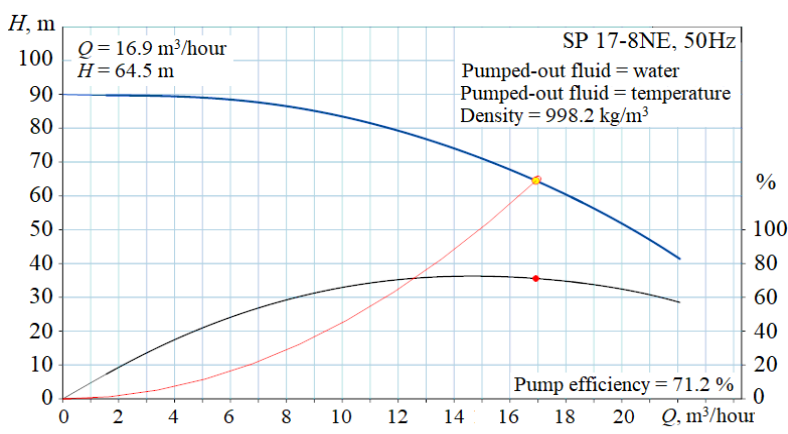

Figure 2. Passport characteristic of the SP-17-8NE pump

For the specified operating conditions of the tandem pumping installation in the extraction well, the parameters of the operating point correspond to the delivery $Q=16.9 \mathrm{~m}^{3} / \mathrm{h}$ and the head $H=64.5 \mathrm{~m}$ with the efficiency of $71.4 \%$.

\subsection{Extraction well virtual model}

Based on the specified operating conditions of the electric-centrifugal pump in actual downhole conditions and the calculation methodology described above, a virtual model of the extraction well has been built with the determination of the maximum possible flow rate of the well $Q$ and the value of the expected dynamic level $H_{d y n}$ during the operation of the tandem pumping installation (Fig. 3).

Based on the modelling the mode of the productive solution inflow into the well, the values of the dynamic level above the pump and pressure at the jet pump suction have been found $\left(Q=1300 \mathrm{~m}^{3} /\right.$ day; $\left.H_{d y n}=63 \mathrm{~m}\right)$.

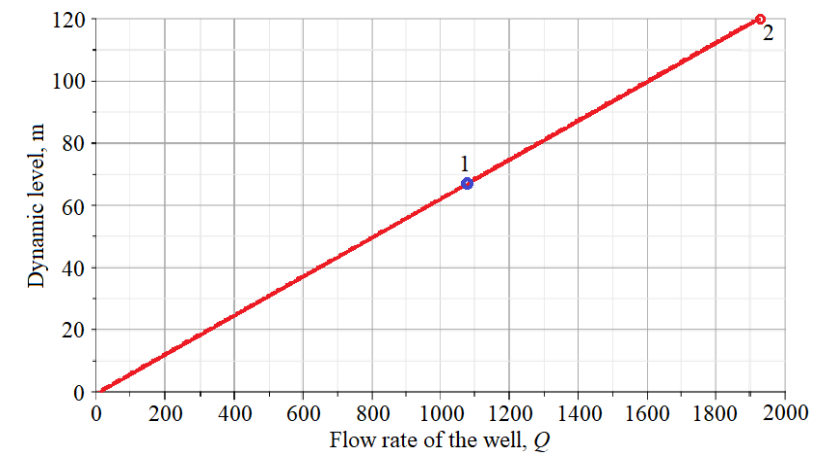

Figure 3. Extraction well indicator curve: 1 -performance curve; 2 - matching point $Q_{\max }$

\subsection{Electric-centrifugal pump virtual model}

The initial passport curve of the electric-centrifugal pump has been reconstructed in Maple software, taking into account downhole conditions in the form of a sixth power polynomial, and operating points have been calculated with a change in the rotation frequency within the range of 35-70 Hz (Fig. 4).

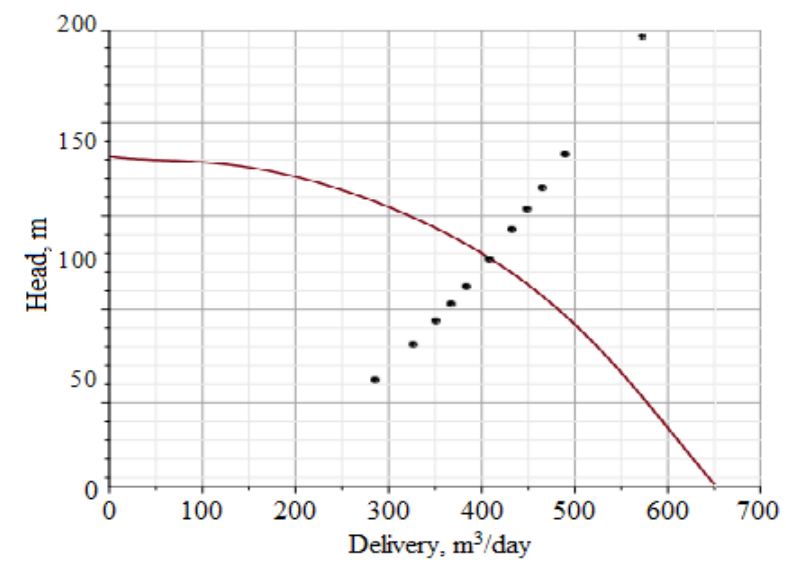

Figure 4. Head-capacity characteristic of the electric-centrifugal pump 17-127 virtual model at $50 \mathrm{~Hz}$ and operating points in the range from 35 to $70 \mathrm{~Hz}$

According to the electric-centrifugal pump modelling results, the pressure value (2.44 MPa) at the jet pump inlet, as well as the value of the electric-centrifugal pump delivery $\left(0.006 \mathrm{~m}^{3} / \mathrm{s}\right.$ or $\left.21.6 \mathrm{~m}^{3} / \mathrm{h}\right)$ have been obtained.

\subsection{Modelling the operating modes of a virtual model of a combined pumping installation}

As a result of the computational modelling, the value of the ejection coefficients has been obtained for different ratios (b); the coefficients of $M_{c}, C R$ and the jet pump efficiency have been calculated; the head curves of the pump have been obtained (Fig. 5 and Table 3).

\section{Discussion}

The computational modeling of the tandem pumping installation operating modes according to the above method makes it possible to determine the rational operating modes of the tandem pumping installation for the specified actual downhole conditions and the design parameters of the jet pump required to ensure them. 


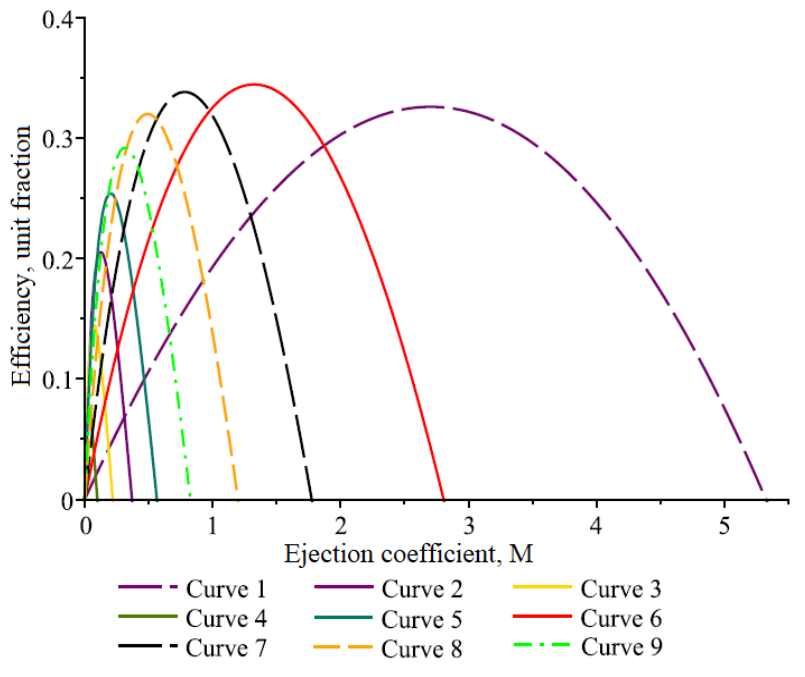

Figure 5. Interrelation of the ejection coefficient $(M)$ and the jet pump efficiency with the different values of $b=0.1-0.9$

Table 3. Calculated data of the joint operation of the "reservoir electric-centrifugal pump-jet pump" system

\begin{tabular}{cccccc}
\hline$b$ & $M$ & Efficiency, $\%$ & $M c$ & $C R, \%$ & $q_{2}, \mathrm{~m}^{3} /$ day \\
\hline 0.1 & 1.80 & 32.6 & 4.22 & 56 & 1029.9 \\
0.23 & 0.88 & 34.5 & 1.88 & 42 & 504.1 \\
0.3 & 0.52 & 33.8 & 1.09 & 40 & 297.5 \\
0.4 & 0.33 & 32.0 & 0.70 & 47 & 187.3 \\
0.5 & 0.21 & 29.2 & 0.47 & 43 & 120.4 \\
0.6 & 0.13 & 25.4 & 0.31 & 48 & 76.9 \\
0.7 & 0.08 & 20.6 & 0.20 & 55 & 47.9 \\
0.8 & 0.05 & 14.5 & 0.11 & 60 & 27.8 \\
0.9 & 0.02 & 7.42 & 0.05 & 55 & 12.8 \\
\hline
\end{tabular}

It follows from the results of computational modeling that the change in the operating modes of the tandem pumping installation is significantly influenced by both the ratio of the nozzle diameter to the mixing chamber diameter $-b$, and the supply voltage frequency $\mathrm{Hz}$ of the electric-centrifugal pump. What is more, the jet pump design parameters have a more significant influence on parameters of the tandem pumping installation. Therefore, the rational operating modes of the tandem pumping installation for specific downhole conditions should be selected with their combined consideration.

According to calculations, the cross-sectional area of the nozzle for the above operating conditions of the tandem pumping installation is $A n=0.1092647857 \cdot 10^{-3} \mathrm{~m}^{2}$. Hence, the nozzle diameter is $D n=11.79 \mathrm{~mm}$. With the determined optimal ratio of the nozzle diameter to the mixing chamber diameter $b=0.23$, the diameter of the latter is $24.6 \mathrm{~mm}$. Taking into account the above design recommendations, the dimensions of the other parameters correspond to the following values: distance between nozzle and mixing chamber - $24.6 \mathrm{~mm}$; mixing chamber length $-196.8 \mathrm{~mm}$.

When choosing a too long mixing chamber, there is a loss of kinetic energy and, as a result, a deterioration in the characteristic of pump head-capacity. According to the experimentally confirmed data for the accepted initial conditions, the optimal distance between the nozzle and the mixing chamber throat is equal to the mixing chamber diameter.

When the distance between the nozzle and the mixing chamber is incorrectly chosen, the kinetic energy loss of the working flow is possible, which can worsen the cavitation stability of the pump and reduce its characteristics. A jet pump with such structural dimensions makes it possible to achieve the highest effective indicators of the combined pumping installation with its relative cavitation-free operation under the specified downhole conditions.

\section{Conclusions}

Based on the results analysis of the computational modelling of the tandem pumping installation operating modes for actual downhole conditions, the following scientific and practical conclusions can be drawn:

1. The method for modelling the jet pump operating modes in downhole conditions makes possible, with sufficient accuracy for practical use, to determine the necessary design parameters of the jet pump main elements to ensure optimal operating modes of the tandem pumping installation when used in extraction wells under different dynamic conditions.

2. The computational model makes it possible to determine the well fluid boundary parameters in the jet pump elements, at which its cavitation-free operation is ensured when the dynamic conditions change.

3. By means of computational modelling, a high sensitivity of the jet pump operating modes to the design parameters of its main elements has been determined, while the tandem installation itself, in general, has a lower sensitivity to changes in dynamic conditions in the well. The latter makes it possible to substantiate that they are promising for their use in downhole conditions when pumping-out productive uranium solutions in the technology of bore-hole in-situ leaching.

4. The use of tandem pumping installation in the technology of bore-hole in-situ leaching can provide an increase in the efficiency of the pumping-out process of productive uranium solutions and reduce the operating expenses of production.

\section{Acknowledgements}

The research was performed at the expense of grant fun-ding from the Ministry of Education and Science of the Republic of Kazakhstan under the project No. AR05131363 "Research and development of techniques and technologies for pumping-out productive solutions in bore-hole in-situ leaching using combined jet pumping installations" on priority "Systems for prospecting, exploration and development of mineral deposits".

The authors express their gratitude to L.A. Krupnik, Doctor of Technical Sciences, Professor of the Department of Technological Machines and Equipment at Satbayev University in the Republic of Kazakhstan for valuable advice and comments when conducting research and writing this paper.

\section{References}

[1] Sherstyuk, A.N., Annikova, Yu.N., \& Ermolaeva, T.A. (2005). Rezhim raboty pogruzhnogo tsentrobezhnogo nasosa dlya dobychi nefti. Khimicheskoe i Neftegazovoe Mashinostroenie, (8), 18-20.

[2] Hassan, M.B., \& Wael, H.A. (2014). Common problems in centrifuga pumps. Pumping Machinery Theory and Practice, 159-203. https://doi.org/10.1002/9781118932094.ch5

[3] Myrzakhmetov, B. A., Krupnik, L.A., Sultabayev, A.E., \& Toktamissova, S.M. (2019). Mathematical model of jet pump operation in tandem oil well pumping unit. Mining Informational and Analytical Bulletin, (8), 123-135. https://doi.org/10.25018/0236-1493-2019-08-0-123-135

[4] Gallyamov, M.N., Batalov, P.M., \& Uzbekov, R.B. (1981). Ustanovlenie optimal'nykh rezhimov ekspluatatsii skvazhin, oborudovannykh UETsN. Neftepromyslovoe Delo, (12), 14-17.

[5] Nyunyaykin, V.N., Generalov, I.V., Zeygman, Yu.V., \& Rogachev, M.K. (2001). Osobennosti ekspluatatsii skvazhin s ETsN na pozdney stadii razrabotki samotlorskogo mestorozhdeniya. Neftyanoe Khozyaystvo, (10), 72-73. 
[6] Verbitskiy, V.S., Grekhov, I.V., Den'gaev, A.V., Drozdov, A.N., \& Markelov, D.V. (2005). Promyslovye issledovaniya nasosno-ezhektornykh sistem “Tandem" v OAO "Yuganskneftegaz". Neftyanoe Khozyaystvo, (4), 5-6.

[7] Drozdov, A.N., Karabaev, S.D., \& Olmaskhanov, N.P. (2020). Issledovanie kharakteristik ezhektorov dlya tekhnologiy neftegazovogo i gornogo dela. Delovoy Zhurnal Neftegaz.Ru, 3(5), 35-42.

[8] Drozdov, A.N., Verbitskiy, V.S., \& Den'gaev, A.V. (2004). Pogruzhnye nasosy i nasosno-ezhektornye sistemy - novye vozmozhnosti v neftegazodobyche, nefteotdache i neftegazosbore. NauchnoTekhnicheskiy Vestnik YuKOS, (10), 3-9.

[9] Kryzhanivskyi, Y.I., \& Panevnyk, D.O. (2019). The study on the flows kinematics in the jet pump's mixing chamber. Naukovyi Visnyk Natsionalnoho Hirnychoho Universytetu, (1), 62-68. https://doi.org/10.29202/nvngu/2019-1/7

[10] Sokolov, E.Ya., \& Zinger, N.L. (1989). Struynye apparaty. Moskva, Rossiya: Energoatomizdat.
[11] Karassik, I.J., Messina, J.P., Cooper, P., \& Heald, C.C. (2007). Pump handbook. New York, United States: McGraw-Hill.

[12] Tishchenko, I.T., Gumerskiy, Kh.Kh., \& Mar'yenko, V.P. (1996). Struynye nasosy dlya dobychi nefti. Moskva, Rossiya: Neft' i gaz.

[13] Teti, M., Spelt, J.K., \& Papini, M. (2018). Jet properties and mixing chamber flow in a high-pressure abrasive slurry jet: part II - machining rates and CFD modeling. The International Journal of Advanced Manufacturing Technology, 101(9-12), 3021-3034. https://doi.org/10.1007/s00170-018-3041-3

[14] Shah, A., Khan, A.H., Chughtai, I.R., \& Inayat, M.H. (2013). Numerical and experimental study of steam-water two-phase flow through steam jet pump. Asia-Pacific Journal of Chemical Engineering, 8(6), 895-905. https://doi.org/10.1002/apj.1734

[15] Winoto, S.H., Li, H., \& Shah, D.A. (2000). Efficiency of jet pumps. Journal of Hydraulic Engineering, 126(2), 150-156 https://doi.org/10.1061/(asce)0733-9429(2000)126:2(150)

\section{Обгрунтування методики моделювання і розрахунку оптимальних} режимів роботи тандемної насосної установки при видобутку урану

\section{Б. Мирзахмєтов, А. Султабаєв, С. Токтамісова}

Мета. Розробка математичної моделі робочого процесу струминного насоса і розрахункової методики для моделювання та визначення оптимальних режимів роботи комбінованої насосної установки у свердловинних умовах.

Методика. При проведенні досліджень вихідною обов'язковою умовою ефективної експлуатації відкочувальних свердловин тандемних насосних установок (ТНУ) було визначення необхідності узгодженої роботи електровідцентрових насосів (ЕВН), струминного насоса $(\mathrm{CH})$ і пласта. Були проведені теоретичні дослідження, що описують роботу СН спільно з ЕВН, використовувалося математичне моделювання роботи системи “продуктивний пласт - EBH - CH" в узгодженому режимі. Як вихідні дані при моделюванні були прийняті конкретні дані рудників родовища "Хорасан-2" (Республіка Казахстан). При моделюванні режимів роботи СН особливу увагу було приділено визначенню граничних параметрів відкачуваного продуктивного розчину, при якому може наступити кавітація. При моделюванні використувався програмний пакет Мaple компанії Waterloo Maple Inc.

Результати. Для оцінки ефективності відкачування зі свердловин продуктивних розчинів урану тандемними насосними установками розроблена математична модель робочого процесу струминного насоса і на його основі складена розрахункова методика моделювання режимів роботи комбінованої насосної установки з імітацією реальних свердловинних умов.

Наукова новизна. В результаті розрахункового моделювання встановлена висока чутливість кавітаційних режимів роботи струминного насоса до конструктивних параметрів основних елементів струминного насоса, тоді як сама тандемна установка, в цілому, має меншу чутливість до зміни динамічних умов. Показано, що застосування тандемної схеми насосів при відкачуванні продуктивного розчину урану може підвищити продуктивність та енергоефективність процесу.

Практична значимість. Методика та алгоритм розрахунку дозволяють 3 достатньою точністю для практичного застосування оперативно розрахувати необхідні геометричні параметри струминного насоса для забезпечення раціональних і безкавітаційних режимів тандемної насосної установки для конкретних свердловинних умов у системі “пласт - електровідцентровий насос - струменевий насос", створити деякі практичні рекомендації з проектування струменевих насосів, що працюють в тандемі із зануреними електровідцентровими насосами.

Ключові слова: моделювання, віртуальна модель, насос, свердловина, сопло, дифузор, видобуток урану, кавітація

\section{Обоснование методики моделирования и расчета оптимальных} режимов работы тандемной насосной установки при добыче урана

\section{Б. Мырзахметов, А. Султабаев, С. Токтамисова}

Цель. Разработка математической модели рабочего процесса струйного насоса и расчетной методики для моделирования и определения оптимальных режимов работы комбинированной насосной установки в скважинных условиях.

Методика. При проведении исследований исходным обязательным условием эффективной эксплуатации откачных скважин тандемных насосных установок (ТНУ) было определение необходимости согласованной работы электроцентробежных насосов (ЭЦН), струйного насоса $(\mathrm{CH})$ и пласта. Были проведены теоретические исследования, описывающие работу СН совместно с ЭЦН, использовалось математическое моделирование работы системы “продуктивный пласт - ЭЦН - СН" в согласованном режиме. В качестве исходных данных при моделировании были приняты конкретные данные рудников месторождения “Хорасан-2” (Республика Казахстан). При моделировании режимов работы СН особое внимание было уделено определению предельных параметров откачиваемого продуктивного раствора, при котором может наступить кавитация. При моделировании использовался программный пакет Марle компании Waterloo Maple Inc.

Результаты. Для оценки эффективности откачки из скважин продуктивных растворов урана тандемными насосными установками разработана математическая модель рабочего процесса струйного насоса и на его основе составлена расчетная методика моделирования режимов работы комбинированной насосной установки с имитацией реальных скважинных условий.

Научная новизна. В результате расчетного моделирования установлена высокая чувствительность кавитационных режимов работы струйного насоса к конструктивным параметрам основных элементов струйного насоса, тогда как сама тандемная установка, в целом, имеет меньшую чувствительность к изменению динамических условий. Показано, что применение тандемной схемы насосов при откачке продуктивного раствора урана может повысить производительность и энергоэффективность процесса.

Практическая значимость. Методика и алгоритм расчета позволяют с достаточной точностью для практического применения оперативно рассчитать требуемые геометрические параметры струйного насоса для обеспечения рациональных и бескавитационных режимов тандемной насосной установки для конкретных скважинных условий в системе "пласт - электроцентробежный насос струйный насос", выработать некоторые практические рекомендации по проектированию струйных насосов, работающих в тандеме с погружными электроцентробежными насосами.

Ключевье слова: моделирование, виртуальная модель, насос, скважина, сопло, диффузор, добыча урана, кавитация

\section{Article info}

Received: 9 August 2019

Accepted: 6 November 2020

Available online: 7 December 2020 